are obtained when the phosphates are treated with sulphuric acid. But this requires pyrites from Spain, which is no longer easy to get, and in any case the resulting sulphuric acid is also needed for making explosives. Other sources of sulphur are, therefore, being exploited, in particular the pyrites and the pyrrhotic deposits of the Eastern States and the sulphur deposits of Louisiana and Texas.

The nitrogen problem is extremely urgent. Chilean nitrates are largely used for making explosives, and are practically unobtainable for agricultural purposes. Prior to the war the largest source of fertiliser nitrogen in the United States had been the various organic products, such as tankage, fish scrap, and cottonseed meal, produced in the country. With the coming of the war, however, other demands have been put upon most of these, and their prices have risen; thus cotton-seed meal is now used as animal food.

Coal is a satisfactory source of nitrogen, one ton of American coal containing on an average $20 \mathrm{lb}$. of nitrogen. The proportion actually recovered, however, is only small, corresponding in I9I 3 with 3 per cent. of the total quantity of coal mined, but a higher recovery is said to be obtained to-day. In r9i 3 about 12 per cent. of the coal (or $69,000,000$ tons) was made into coke, but threequarters of this was done in the old bee-hive oven, and only a quarter in the more modern ovens from which recovery of the nitrogen is possible. This proportion, however, is steadily increasing.

All these methods are essentially transitory; they come to an end in that indefinite time when coal and nitrate of soda are both exhausted. The permanent, never-failing supply is the atmosphere. Already calcium nitrate, cyanamide, and ammonia are produced synthetically, but of these only cyanamide is as yet made in North America, and that only on the Canadian side of Niagara. The need, however, is fully recognised, and the work is being vigorously pushed forward. The sum of twenty million dollars was appropriated in 1916 for the construction of the plant, and although the scheme is not yet in working order, we may be sure that it will materialise. The peculiar and profound importance of these synthetic processes as the central feature of the war is fully recognised, and, as the author of the Bulletin justly remarks: "It is significant that war was declared directly after the successful development of the Haber and cyanamide processes in Germany."

The dependence of the civilised world on Stassfurt for its necessary potash was accepted as a natural and fundamental fact prior to the war, and very little was done to obviate it. Potassium is extremely common; only seven other elements are more abundant, and it is calculated that there is more potash in the earth's crust than water. But, unfortunately, workable deposits are rare, and only the one at Stassfurt is actually worked to any notable extent. For some time before the war the United States Government NO. $25 \mathrm{I} 7$, VOL. IOO] recognised the drawbacks of the position, and caused a systematic search to be made for potash within its own borders. A limited amount of potash can be obtained from the wood-ashes of the lumber industry in Michigan and Wisconsin. Another source is the mineral alunite, a potassium aluminium sulphate occurring in moderate-sized deposits in Utah. Another, again, is kelp produced from the giant seaweed of the Pacific coast from Lower California to Alaska. A more important source is the flue-dust obtained from Portland cement works and from blastfurnaces. Still more important from the point of view of immediate production are the alkali lakes of the West, which at present yield most of the American supply: Jesse Lake, in western Nebraska, supposed to derive its potash from the forests burnt on the adjacent plains; Searles Lake, in California, reputed to contain great quantities of potash, though there are so many other salts as well that the extraction is by no means simple; Owen's Lake, also in California, several lakes in Oregon and elsewhere. In addition, there are salt beds in Texas, Oklahoma, and other places where some of the underlying strata were formed in arid climates.

There are still other possibilities which have not yet come to anything, though they are not without promise for the future: felspar, which occurs in scattered and rather small deposits; leucite, forming a conspicuous component in a rock mass of considerable size in Wyoming; sericite, which forms extensive beds in Georgia; and greensand, found widespread in the Atlantic coastal plain, especially in New Jersey. All these are open to exploitation.

But what will be the future of these new fertiliser industries, assuming they mature? Will they disappear after the war, choked by the competition of German products, or will they be kept alive by artificial support? This is a political question scarcely less important than the chemical and engineering problems involved, and one which we may be sure will receive serious and systematic consideration.

E. J. Russell.

\section{WHAT DETERMINES STATURE? 1}

DR. C. B. DAVENPORT has collected data in regard to human stature, and analysed them by modern methods of studying heredity. Some of the data refer to 2354 children of parents whose height is recorded, but the precision of this recording was very unequal. The other data refer to the inheritance of stature in families, and these, while less numerous, are more uniformly precise.

For the class of people dealt with, it appears that nutrition is not of much importance in determining stature. It is improbable that insufficient or improper food counts for much in determining eventual height; "temporary starvation has little or no effect on the end result. So, likewise,

1 Bulletin No. 18 , "Inheritance of Stature." Pp. $3^{1} 3-89+33$ tables and ig figs. (Eugenics Record Office, Cold Spring Harbour, N.Y., x $\mathbf{1}_{7}$.) Price 40 cents. 
overfeeding, however much it may affect weight, has probably little effect on adult stature, though it may hasten growth and thus enable a man to reach precociously his predestined stature." Of great importance, however, are the internal secretions of the gonads, the thyroid, the pituitary body, and other endocrine glands. The degree of activity exhibited by these glands is a variable and heritable constitutional character, but it is also modifiable by severe diseases and accidental extrinsic influences. In two ways, therefore, stature is affected by the degree of activity of the ductless glands, and "experience points strongly to the conclusion that internal constitutional factors are more important than the ordinary environmental differences."

The following are among the nost important conclusions which Dr. Davenport has reached. One of the factors determining variation in stature is variation in the age of the onset of puberty. Parents deviating from the mean in the same direction have on the average less variable offspring than those of one short and one tall parent. The offspring of two tall parents are less variable in stature than those of two short parents. When the stature of both parents is very much above or below the average, the children tend to repeat it, especially in the direction of tallness. When the parents are much below the average the offspring regress towards mediocrity, but there is no (or little) filial regression when the parents are much above the average. It seems that parents of all statures are somewhat heterozygous (or "impure") as regards their peculiarity, but there is evidence in favour of the theory that in tall parents the gametes are more nearly homogeneous (in lacking most of the shortening factors) than are those of "short" parents. Shortness seems to be due to certain positive factors which inhibit the growth of various parts. It appears that "growth-as-a-whole" factors are present, but there is a large degree of independence in the variability of the four segments of stature (head and neck, torso, thigh, and lower leg); and this makes impossible any simple "Mendelian" laws of the inheritance of stature as a whole.

There is evidence that peculiarities in the separate segments of stature are independently heritable, and the combinations of types with different proportions (though similar in total stature) may give curious, but readily intelligible, results. The proportional shortness of any segment depends on more than one shortening factor - just how many cannot be said. It is probable that in all forms of dwarfing there are multiple dominant inhibiting factors. In the case of gigantism in both parents all the children are tall; "this indicates that the factors for tallness are mostly recessive-probably due to the absence of inhibitions to prolonged growth." "Persons of similar stature tend to marry each other; and extremes are more particular in this respect than those of medium statures."

These are the most important conclusions of this interesting piece of work, but it is evident that "the classic topic of the heredity of human stature" must be subjected to further analysis with even larger bodies of data. In admitting the provisional character of his investigation, Dr. Davenport says: "If the work has done nothing more than prove, what might have been anticipated, that the apparent blending inheritance of stature is due merely to the presence of multiple factors, it may be justified."

\section{NOTES.}

IN various parts of the country camouflaged houses and hangars and vessels are to be seen by those who have eyes to see, and it was stated officially on January I4 that the Admiralty had tested many methods of disguising mercantile shipping. One of these methods is to paint the ship with various quaint combinations of different colours. But this does not appear to have proved much of a success, though we know in Nature of conspicuously patterned creatures, such as the hoopoe, which are, in certain situations and poses, endowed with what amounts to a garment of invisibility. Another method, well illustrated by a model in the British Museum (Natural History), depends on what is sometimes called Thayer's law, the announcement of which was first made in NATURE of April 24, 1902, by Prof. E. B. Poulton. A further illustrated description of the principle was given in an article in our issue of October 27, I9Io. Mr. Abbott $\mathrm{H}$. Thayer, an American artist, was one of the first to recognise that a high degree of invisibility is conferred on certain birds by the simple adaptation of being dark above and whitish below. He took two wooden decoy ducks, and placed them against a sandbank. One was coloured like the sand, or coated with sand; the other was coloured on its upper parts darker than the surrounding sand, and graded below to pure white. At a short distance the first was still clearly visible, but the second was quite lost against its background. The first bird was revealed by the dark shadow below it; the second was made invisible because the light lower parts were neutralised by the shadow, while the dark upper parts were toned down by the strong direct light. The result is technically described as obliteration by counter-shading. Some modification of this experiment has been tried on ships by differential painting, but this device has not proved so successful as had been hoped by those who knew how obliterative it was in some birds and fishes. On some other quite different line, it is said, the Admiralty has discovered a system of camouflage which will go far to baffle the eyes of submarines.

IT would appear from some recent statements by the Ministry of Munitions that the production of mineral oil from native sources is engaging the close attention of the Department of Mineral Oil Production. It may be inferred that boring for petroleum in Great Britain has not yet been attended with any success, and so far the opinions of the large body of British geologists who were opposed to these boring operations appear to have been justified. Oil has, of course, continued to be produced in Scotland by the distillation of the so-called oil shales of the Carboniferous Measures, and it appears that the output of this oil is being pressed to the utmost. It has been known for many years that the Kimmeridge shales of Liassic age in the south of England are in places quite rich in oil, and a succession of companies has attempted in the past to create there a shale-oil industry on the same lines as

No. $25 \mathrm{I} 7$, VOL. IOO] 